Article

\title{
Improvement of the Plantation Success in a Crib Wall in a Mediterranean Hydro-Meteorological Risks Scenario-Practical Results
}

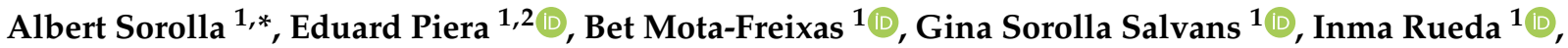 \\ Adrian Lochner Prats ${ }^{1}(\mathbb{D})$ and Clara Unzeta ${ }^{1}$ (D) \\ 1 Naturalea Conservació SL, 08211 Castellar del Vallès, Spain; eduardpiera@naturalea.eu (E.P.); \\ betmota@naturalea.eu (B.M.-F.); ginasorolla@naturalea.eu (G.S.S.); inmarueda@naturalea.eu (I.R.); \\ adrianlochner@naturalea.eu (A.L.P.); claraunzeta@naturalea.eu (C.U.) \\ 2 CREAF, Centre de Recerca Ecològica i Aplicacions Forestals, 08193 Cerdanyola del Vallès, Spain \\ * Correspondence: albertsorolla@naturalea.eu; Tel.: +34-93-730-1632
}

\section{check for} updates

Citation: Sorolla, A.; Piera, E.; MotaFreixas, B.; Sorolla Salvans, G.; Rueda, I.; Lochner Prats, A.; Unzeta, C. Improvement of the Plantation Success in a Crib Wall in a Mediterranean Hydro-Meteorological Risks ScenarioPractical Results. Sustainability 2021, 13, 11785. https://doi.org/10.3390/ su132111785

Academic Editor:

Alejandro Gonzalez-Ollauri

Received: 2 July 2021

Accepted: 18 October 2021

Published: 25 October 2021

Publisher's Note: MDPI stays neutral with regard to jurisdictional claims in published maps and institutional affiliations.

Copyright: (c) 2021 by the authors. Licensee MDPI, Basel, Switzerland. This article is an open access article distributed under the terms and conditions of the Creative Commons Attribution (CC BY) license (https:// creativecommons.org/licenses/by/ $4.0 /)$.

\begin{abstract}
Due to the clime change scenario, severe hydro-meteorological phenomena are having a high impact on the ecosystems of the earth. Some strategies based on the use of natural communities associated with geomorphological changes that restore the natural landscape are gaining success due the resistance and resilience against damages. All of these strategies are known as nature-based solutions (NBS). Soil and water bioengineering techniques are one of the most appreciated tools to reach effectiveness for slope stabilization. They are based on the capacity of some plants to consolidate the soil with his rooting system in special conditions (high slope, flooding impact). Slope stabilization solutions with soil and water bioengineering techniques need to be adapted to this new scenario. Crib wall is one of the most complete soil and water bioengineering technique for structural slope stabilization. It is based on a wooden box full of live plants that in the future will grow and gain stability at the same time that wood decays. The crib wall box is full of soil, and the front area is traditionally stabilized with some branches of fascines to let plants grow, maintaining the structure. Fascines are made of branches of riparian species with the capacity for vegetative propagation. Their diameter can change due to the humidity variation, so the stiffness of the system is at risk against severe hydro-meteorological phenomena. This study aims to assess that the introduction of HDCL in crib walls improves planting success and makes them more resistant to adverse weather events in Mediterranean areas. Four experiments were performed in controlled and natural conditions with this proposal. The results show that the use of natural fibers instead of branch fascine helps to maintain the humidity conditions and increase the resistance capacity. High-density coir logs (HDCL) are not affected by volume changes for humidity conditions. HDCL maintains the plant's humidity conditions longer and makes plants grow faster, bigger and increase their survival. This method of Crib wall construction increases the associated biodiversity. The most important results are that the use of HDCL in crib walls has an effect on the growth of planted shrub, the development of roots, the colonization of native vegetation and ultimately, the resistance of the structure to the floods. The results also show that crib walls are a good technique for the stabilization of slopes with considerable gradients and high hydraulic impacts. HDCL can reduce the water stress of plantations, and they can be a good system to retain runoff and provide it to the plants. Finally, the HDCL allows the revegetation of a crib wall $30 \%$ faster than with branch fascine.
\end{abstract}

Keywords: soil bioengineering technic; slope stability; crib wall; high-density coir log (HDCL)

\section{Introduction}

A crib wall (Figure 1) is one of the most widely used soil bioengineering techniques, consisting of wooden structure logs forming a three-dimensional cell backfilled with soil. On the front of the crib wall are placed live stakes or container plants, with the aim that the 
future development of the plants replaces the structure of logs [1]. The crib wall structure is linked to the history of civilization. There are foundations of crib walls on Roman bridges 2000 years BP. The walls of the Celtic villages were likely a type of crib wall. However, it is not easy to find shreds of evidence of these works. Pareto [1886] describes the origin of the crib wall technique, which reports examples of log revetments proposed by Sir Culmann for the Eschibach torrent control near Berna with wood structure and stones [2]. However, the current log-wood crib wall system in slopes was originally developed in a place called "Kranj" in north Slovenia. This wall system is famous under the name "Krainerwand" in German-speaking countries [1]. Today, the word Krainer is a popular name for a vegetated crib wall of double wall.
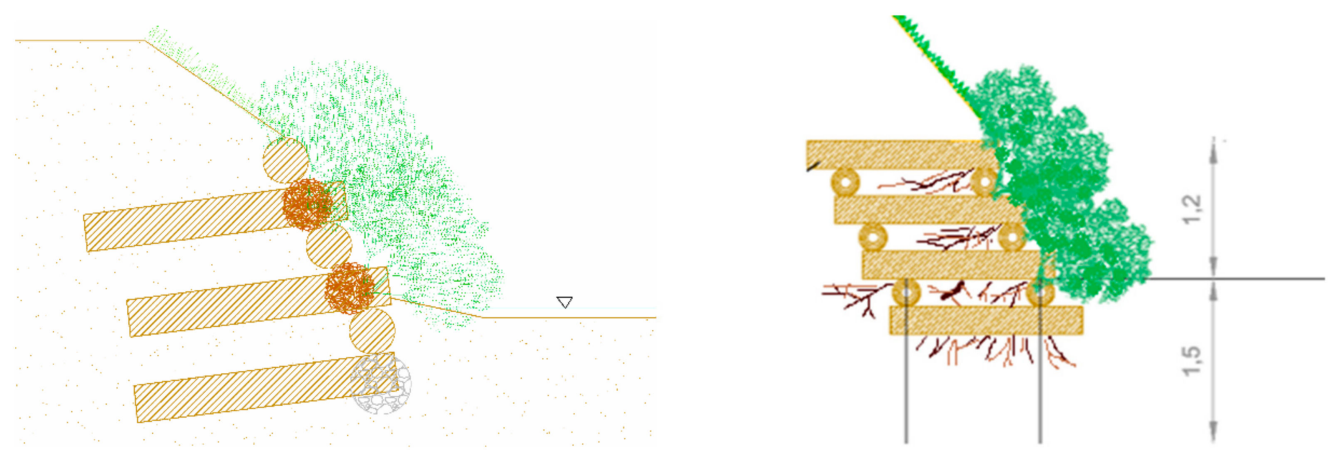

Figure 1. Scheme of a traditional crib wall simple (left) or double or Krainer (right).

In the eastern Alps, crib walls were a usual slope retention system and were made of wooden boxes filled with rocks [3], but this system has a relatively short shelf life due to the durability of the deadwood. In 1934, Hassenteufel introduced willow plants instead of rocks; the plants occupied the space of the rotting lumber, and the structure became permanent. The only change is the slope that they valued in a proportion of 1:10 [4]. In order to keep the soil in the structure and let plants grow, a plant fascine is used to close the holes between trunks in the front area. Fascines come from the Latin "fascinare", which means binding bundling. This fascine develops an essential role in moisture retention. Schemerl, in 1818 [4], already reported the use of fascines for streambank protection [3]. The evolution of this system is used worldwide today.

The actual crib walls are the evolution of the Hassenteufel works. The decomposition of the wood accelerates in the surface of the cut and the holes of subjection (for nails or corrugated bars). Therefore, today, we construct crib walls in the simplest way: without laces of wood and nails to achieve resistance

The structure always needs a foundation, determined according to its location. Depending on the level of transient erosion, the depth at which the structure must be anchored is established. If a crib wall is used as a structural wall to stabilize margins and the structure must support heavy loads, it is recommended reinforced crib wall with double-wall or Krainer. The front of the live crib wall has to be inclined to reach a maximum slope gradient of $60^{\circ}$. When the crib wall is lifted, the logs that follow the line of elevation in the length of the structure are placed down until they are aligned with the back of the lower log.

Fascines are made by branches of trees and shrubs generally collected close to the job side area. It is clear that most of the usual trees used have a big variation in volume due to the variations in climatic conditions. Wood is a hygroscopic material in which the space between its microfiber varies according to the water content (Table 1). As a result, the volume of the wood increases with moisture and decreases with drying as long as the fibers are not saturated with moisture. Volumetric contraction is the property used to measure the increase (swelling) or decrease (decrease) in the volume of wood when taking or giving water from or to the environment. In addition, there is also the coefficient of volumetric contraction, used to measure the volumetric variation in a wood that, below the saturation 
point of the fibers, varies its moisture by $1 \%$ [5]. The data show that in the case of a fascine made from all wood, the volumetric concentration changes are between $13 \%$ and $17 \%$.

Table 1. Volume variation in the different woods according to the water content [5].

\begin{tabular}{ccc}
\hline & \% Volumetric Concentration & $\begin{array}{c}\text { \% Volumetric Concentration } \\
\text { Coefficient }\end{array}$ \\
\hline Castanea sativa & 8.7 & 0.396 \\
\hline Fraxinus excelsior & 13.31 & 0.55 \\
\hline Pinus halepensis & 14.13 & 0.45 \\
\hline Pinus pinsaster & 14.63 & 0.34 \\
\hline Pinus sylvestris & 15.62 & 0.34 \\
\hline Platanus x hispanica & 16.42 & 0.61 \\
\hline Quercus cerrioide & 13.24 & 0.45 \\
\hline
\end{tabular}

If fascines located in crib wall reduce their diameter, three situations can happen: the soil can escape, air can enter and dry the roots, or water can enter during storms and empty the crib wall wooden box. For this reason, in the last years, in several bioengineering works but especially in crib walls in the Mediterranean area, we used coconut HDCL instead of fascines. The coir, coconut fiber (Cocos nucifera L.), are the longest stable natural fibers because of its peculiar proprieties such as the high percentage of lignin, the $41-45 \mathrm{wt} \%$ [6]. In 1976, Lothar Bestmann (in Hamburg, Germany) began a line of slope bioengineering works based on the use of high-density coir logs (HDCL). As a result, plants developed a root system within the fibers before their degradation and took advantage of the fibers moisture. The HDCL is a hydrodynamic structure formed by a compressed and structured coconut fiber cylinder with a polypropylene/coir net that can withstand long periods of significant water passages at high speeds together with the fixing of stakes and rope.

Depending on the high density, a coir log fiber can be washed apart. After years of research based on practical works, the standard stock item Naturalea develops quality criteria (unpublished data). The coir rolls (HDCL) are manufactured from coir fiber with a mean fiber length of $150 \mathrm{~mm} \pm 50 \mathrm{~mm}$, compressed to a density of $110-120 \mathrm{~kg} / \mathrm{m}^{2}$ and contained by a net of $2 \mathrm{~mm}$ PP yarn or $5 \mathrm{~mm}$ coir yarn with a mesh size of $50 \mathrm{~mm}$. The dry weight is $9 \pm 0.5 \mathrm{~kg} / \mathrm{lin} . \mathrm{m}$. Regarding the wet weight, we established the criteria $1 \mathrm{~h}$ after removal from the water to be approx. $20.6 \mathrm{~kg} / \mathrm{lin} . \mathrm{m} . ; 4 \mathrm{~h}$ after removal from the water, it was established to be approx. $16.7 \mathrm{~kg} / \mathrm{lin} . \mathrm{m}$. Finally, when subjected to a load of $80 \mathrm{~kg}$, the Coir roll compresses less than $15 \%$ (this load approximates to an $80 \mathrm{~kg}$ man standing on the roll) $[6,7]$.

This paper aims to analyze how to improve plantation success, and one of the tools is the use of coconut HDCL in crib walls.

In order to obtain a more systematic analysis, we evaluated four different parameters or characteristics:

(A) Improve the resistance to hydro-meteorological hazards. In order to establish if HDCL structures resist flooding events, and especially areas with high flooding, we obtain data on shear strength, velocity and peak flow from the avenues that affected the works carried out with this product/technique;

(B) Effects of HDCL on the growth and survival of plants. Especially establishing if HDCL in arid conditions will compete for water with roots and dry out the plant;

(C) The colonization of HDCL by plant roots in comparison to standard soil mixture in natural areas or with nursery plants. To obtain faster root growth, we used helophyte plants;

(D) The success of crib wall soil bioengineering works with different characteristics and scenarios with the use of HDCL. 


\section{Material and Methods}

\subsection{Improving HDCL Resistance to Hydro-Meteorological Hazards}

\subsubsection{Study Sites and Experimental Design}

In order to establish the resistance of vegetated HDCL, an analysis of the conservation conditions of vegetated fiber rolls (HDCL) installed in rivers was performed. We consider that conservation conditions are good when the plants are regularly distributed and maintain the initial structure of hard density in $30 \mathrm{~cm}$ diameter. We selected different case studies in which HDCL were installed directly (Table 2). In crib walls, the HDCL has extra protection because it has wooden trunks in all the perimeter. We selected several job sites where vegetated HDCL fiber rolls were installed; interventions that we carried out in the Mediterranean area in twelve different locations throughout Catalonia (northeastern area of Spain). A set of study areas with jobs conducted between 2000 and 2009 was chosen, and we obtained official data from the Catalan Agency of Water to establish the flood events that affected the different places.

Table 2. Data and characteristics of the interventions. Improving HDCL for resistance to hydro-meteorological hazards.

\begin{tabular}{|c|c|c|c|}
\hline Place & Date of Installation & $\begin{array}{l}\text { Lineal Meters of Coir } \\
\text { Roll Instaletaed }\end{array}$ & Vegetation Planted Present \\
\hline $\begin{array}{l}\text { Fluvià river, Pont de } \\
\text { les mores (Olot) }\end{array}$ & May 2007 & 70 & $\begin{array}{c}\text { Carex pendula, absence of Iris pseudacorus } \\
\text { and Scirpus holoschoenus }\end{array}$ \\
\hline $\begin{array}{c}\text { Anoia River, Sant Esteve de } \\
\text { Ses Rovires }\end{array}$ & 2007 & 50 & It was not possible to find the fiber roll. \\
\hline Riu Mogent, Llinars del Vallès & 2003 & 40 & $\begin{array}{c}\text { There are no Scirpus holoschoenus or Carex } \\
\text { vulpina. Iris pseudacorus occupies the entire } \\
\text { fiber roll. }\end{array}$ \\
\hline Fluvià River, Besalú & 2008 & 40 & $\begin{array}{l}\text { There are new species in the fiber roll: } \\
\text { Typha sp. The fiber roll is now composed of } \\
\text { Iris pseudacorus, Carex pendula, Scirpus } \\
\text { holoschoenus and Carex vulpina. }\end{array}$ \\
\hline Congost River, Granollers & 2008 & 50 & $\begin{array}{c}\text { There are no Carex vulpina, and Scirpus } \\
\text { holochoenus is scarce. The main abundance } \\
\text { is of Iris pseudacorus, with the presence of } \\
\text { Scripus holoschoenus and Lythrum. }\end{array}$ \\
\hline $\begin{array}{c}\text { Besós River, Montcada i } \\
\text { Reixac }\end{array}$ & 2001 & 20 & $\begin{array}{c}\text { There is Typha sp. and Urtica sp. The main } \\
\text { abundance is of Iris pseudacorus, with less } \\
\text { abundance of Scripus holoschoenus and } \\
\text { Carex pendula. }\end{array}$ \\
\hline $\begin{array}{l}\text { Torrent de Vallcorba, Sant } \\
\text { Quirze del Vallès }\end{array}$ & 2009 & 50 & $\begin{array}{c}\text { The prevalent species is Iris pseudacorus, } \\
\text { followed by Carex vulpina and Scirpus } \\
\text { holoschoenus. }\end{array}$ \\
\hline
\end{tabular}

\subsubsection{Sampling Design and Data Collection}

All the study areas were visited, and to obtain data from the area, we made a crosssection of the river and obtained data on the lithology of the river banks. We found that the HDCL vegetated has vegetation in all lengths and that the roll maintains the volume, so there are no holes due to fibers being dragged away. The data on peak flow and water speed that affects the area since HDCL implementation were selected from the automatic register of the nearest gauging station in each study area, provided by the Catalan Water Agency.

\subsubsection{Data Calculation and Statistical Analysis}

Hydraulics of the study area were analyzed, considering shear stress, flow and peak velocity from the implementation until now. The hydraulic study was carried 
out with the Manning formula and Master Flow software; bed shear stress (BabaeyanKoopaei et al., 2002).

\subsection{Influence of HDCL on Growth and Survival of Plants}

\subsubsection{Study Sites and Experimental Design}

We carried out a specific design located in the Urban River Lab experimental facility (http:/ / www.urbanriverlab.com) (accessed on 17 October 2021), which is outdoor research (mesocosm) located in Montornès del Vallès (Barcelona, Catalonia). The facilities are located on one of the quaternary terraces of the Besòs River. The composition oef the soil is basic, with a dominated granulomere of silts, clays and gravels.

The experimental setting consisted of 3 parallel lines of $18 \mathrm{~m}$ in length, which were planted in a line, with a spacing of $0.5 \mathrm{~m}$ from each other (Figure 2). A total of 36 plants were in the forestry cell, which came from a plant nursery. The first planted line did not have coconut HDFL (control); the second one had a line of coconut HDFL $30 \mathrm{~cm}$ in diameter, tied in coconut net partially buried next to it (treatmentF1); and the third line had between 2 parallel lines of HDFL that separated $0.5 \mathrm{~m}$ (treatment F2). In each planting line were placed 12 individual plants from each species that are widely used in bioengineering in Southern Europe, especially in Mediterranean regions: Viburnum tinus L. (an evergreen shrub widely distributed [8]), Pistacia lentiscus L. (another evergreen shrub or small tree that is 1-8 m tall, which grows in many Mediterranean countries) [9] and Lavandula angustifolia L. (widely distributed aromatic herb [10]).

18

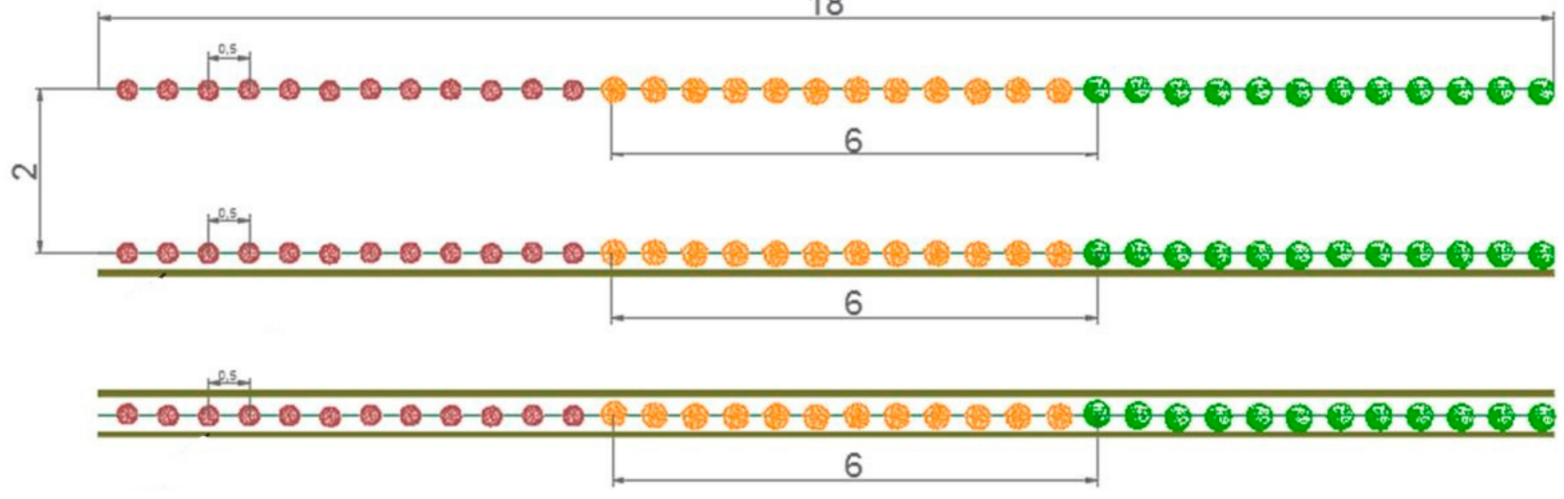

Figure 2. Experiment design to test the effects of HDCL on growth and survival of plants. Brown: Viburnum tinnus; orange: Lavandula angustifolia; green: Pistacia lentiscus.

Throughout the experiment, these adventitious plants were manually extracted and watered on the day of planting and three more times before sampling with the amount of water proportional to the average rainfall in autumn in Montornès del Vallès.

\subsubsection{Sampling Design and Data Collection}

The sampling period began three months after planting, once the plants had adapted to the new conditions. From the first sampling time, in September, the sampling frequency was set at 20 days. Five samplings were carried out (day 90, 110, 130, 150 and 176).

For each plant and sampling day, we measured the following parameters: aerial diameter-in order to establish the vertical development of the plant, the aerial height was measured; in order to establish the vigor of the plant, a visual estimate of the percentage of the living plant and a mortality count was provided.

\subsubsection{Data Calculation and Statistical Analysis}

To analyze the success, we selected three parameters: number of dead plants, the height of the plant and the diameter as data of horizontal volume growth. In order to compare diameter and high growth (dependent variables) for each of three species plants 
between treatment, we performed the analysis using a repeated-measures analysis of covariance (RM-ANOVA), with the repeated measure "day". Data were examined for homogeneity of variances (Levene's test, $p>0.05$ ) and for normality of the variables (Shapiro-Wilk test). Multiple comparisons were made among treatments following a post hoc Tukey HSD procedure in all significant RM-ANOVA tests. Finally, we examined the relationships between mortality by species between treatment using a contingency table. Significance was determined by Fisher's exact test to identify correlations within small data sets. All statistical analysis was completed using R statistical language (R Core program).

\subsection{Colonisation of HDCL by Roots}

\subsubsection{Study Sites and Experimental Design}

In these recent years, we performed some research that shows the capacity of a plant root system to colonize HDCL. We tested helophytes and riverside shrubs and trees, all function, but clearly, helophytes have faster growth. In this step of the experiment, we want to certify that a plant can grow faster in a coir log than in a natural environment. The experiment set was carried out in 3 different environments.

In Aquanea's plant nursery, in Terrassa (Barcelona), we planted helophytes of the same side and age in two different substrates in coir logs (HDCL) and in soil subtract specially prepared to easily grow the plants (Figure 3).
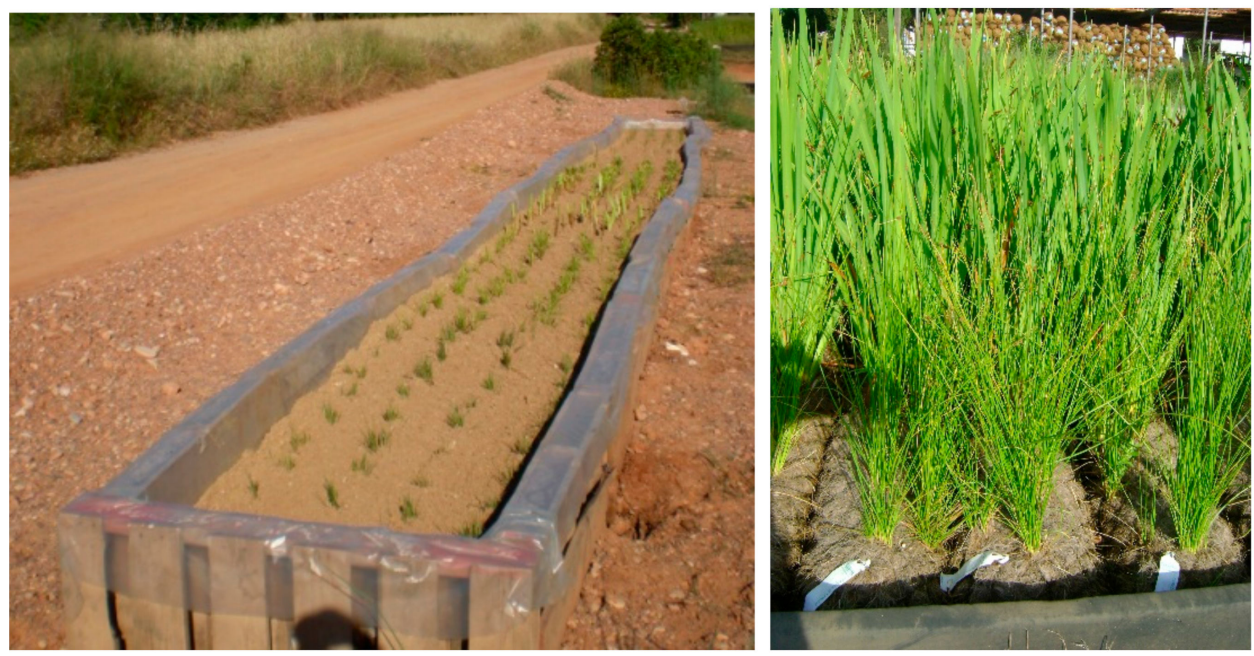

Figure 3. Planter and a pool where helophytes were planted in Aquanea's plant nursery.

A special planter area was built, and six wetland native species (Carex vulpina L., Carex pendula L., Iris pseudacorus L., Phragmites australis L., Scirpus holoschoenus L. and Juncus inflexus L.) were planted in a build size of $12 \mathrm{~m} \times 0.8 \mathrm{~m} 125 \times 1 \mathrm{~m}$ (length $\times$ width $\times$ height). The granulomere composition was gravel sands, a low proportion of fines. The distance between specimens was $20 \mathrm{~cm}$, and 240 specimens were planted.

On the same day, we also planted some HDCL in a special pool semi-submerged in water. The vegetated fiber roll model was selected as it contains four of the six species (Carex vulpina, Iris pseudocorus, Scirpus holoschoenus and Juncus inflexus). In HDCL, helophytes were planted only in a line so that the distance between specimens was $20 \mathrm{~cm}$.

For the third study, we selected two natural well-conserved environment areas where we removed some natural exemplars of the same helophytes selected for plants in the nursery. Two areas were selected in Natural Park Aiguamolls de l'Empordà (Girona).

\subsubsection{Sampling Design and Data Collection}

To analyze the root growth capacity and to enable comparisons between environments, several variables were taken: stem diameter, aerial height, aerial width, the root system's depth, the root system's width and the root system's volume. 
- $\quad$ Soil planter. Sampling was carried out monthly over six months. We extracted 6 specimens of each species each month after taking aerial measures (stem diameter, aerial height, aerial width);

- Vegetated coir fiber rolls (HDCL). Due to the characteristics of the fiber rolls, 3 specimens of the Carex vulpina, Iris pseudocorus, Scirpus holoschoenus and Juncus inflexus were measured and extracted every two months. When the plants are rooted to the fibers of the fiber roll, it is difficult to extract the specimens. The roots entangle with the fibers, and it is necessary to disassemble most of the fiber roll, as it was also difficult to distinguish them by eye. As some species have more than three specimens of species in the FR-N1 fiber roll, the selection of the specimens was achieved at random. The same measurements as in the soil planter were made;

- Natural specimens. Three individuals of each six species were extracted in one single sampling in a natural area. Carex vulpina, Iris pseudocorus and Juncus inflexus were extracted in Castelló d'Empúries, Scirpus holoschoenus, Carex pendula and Phragmites australis were extracted from Aiguamolls de l’Empordà Natural Park.

\subsubsection{Data Calculation and Statistical Analysis}

From recollected data, four indexes were calculated, which indicate the helophytes' stability and solidity: relative stability index $(\mathrm{S}=$ root system's depth/aerial height), relative solidity index ( $\mathrm{s}=$ root system's width/aerial width), root system stability $(\mathrm{R}=$ Relative stability $*$ relative solidity) and global stability $\left(\mathrm{P}=\right.$ Relative stability $*$ relative solidity $\left.{ }^{2}\right)$.

We calculated the differences between the 4 roots growth index mentioned for each species and treatment using the one-way ANOVA statistical test. Multiple comparisons were made among treatments following a post hoc Tukey HSD procedure in all significant ANOVA tests. In species that could only be measured in two environments, Welch's $t$-test was calculated. We applied the Shapiro test to observe if the indexes followed a normal distribution. All statistical analysis was completed using R statistical language.

2.4. Success of Crib Wall Soil Bioengineering Works with Different Characteristics and Scenarios Using $H D C L$

2.4.1. Study Sites and Experimental Design

For compliment of these objectives, we included a set of works that involve crib wall techniques carried out in the Mediterranean area in different locations throughout Catalonia (Table 3). We constructed a list of all the works that involve crib walls that we performed in the province of Barcelona and Girona. The crib walls selected should be more than $5 \mathrm{~m}$ long.

\subsubsection{Sampling Design and Data Collection}

We visited all works on site to observe their naturalization between 2020 and 2021. Naturalized: when a crib wall appears completely covered by vegetation, just a detailed observation shows the original structure. We also observed whether holes and the origins were visible: all are by water income in the fascine areas. 
Table 3. Data and characteristics of the selected Crib wall interventions.

\begin{tabular}{|c|c|c|c|c|c|c|}
\hline Works & Type & Location & Foundation & Main Structure & Wood Spices & $\begin{array}{c}\text { Date of } \\
\text { Construction }\end{array}$ \\
\hline $\begin{array}{c}\text { Sant Cugat Stream } \\
\text { Can Cabassa }\end{array}$ & $\begin{array}{l}\text { E. KRAINER } \\
\text { E.SIMPLE }\end{array}$ & FLUVIAL & $\begin{array}{c}\text { tubular flexible } \\
\text { gabion }\end{array}$ & HDFL & Castanea sativa & November 2016 \\
\hline $\begin{array}{l}\text { Palausolità i } \\
\text { Plegamans Riera } \\
\text { Sentmenat }\end{array}$ & E. KRAINER & FLUVIAL & fascine & fascine & $\begin{array}{c}\text { Robinia } \\
\text { pseudoacacia }\end{array}$ & December 2011 \\
\hline $\begin{array}{c}\text { Cànoves Riera de } \\
\text { Cànoves }\end{array}$ & E. KRAINER & FLUVIAL & fascine & fascine & Castanea sativa & March 2016 \\
\hline $\begin{array}{c}\text { Santa Eulalia de } \\
\text { Ronçana.River } \\
\text { Tenes }\end{array}$ & E. KRAINER & FLUVIAL & $\begin{array}{c}\text { tubular flexible } \\
\text { gabion }\end{array}$ & HDFL & Castanea sativa & $\begin{array}{c}\text { October / } \\
\text { December } 2011\end{array}$ \\
\hline $\begin{array}{c}\text { Santa Eulalia de } \\
\text { Ronçana.River } \\
\text { Tenes }\end{array}$ & E. KRAINER & FLUVIAL & $\begin{array}{c}\text { tubular flexible } \\
\text { gabion }\end{array}$ & $\begin{array}{c}\text { tubular flexible } \\
\text { gabion }\end{array}$ & Castanea sativa & December 2016 \\
\hline $\begin{array}{l}\text { Sentmenat } \\
\text { Foodpath slope } \\
\text { stabilization }\end{array}$ & E. KRAINER & SLOPE & $\mathrm{NO}$ & fascine & Castanea sativa & November 2010 \\
\hline $\begin{array}{c}\text { La Garriga. River } \\
\text { Congost }\end{array}$ & E. KRAINER & FLUVIAL & FEIXINA VIVA & fascine & Castanea sativa & March 2010 \\
\hline $\begin{array}{l}\text { Vacarisses-Urban } \\
\text { slope stabilization }\end{array}$ & E. KRAINER & SLOPE & $\mathrm{NO}$ & HDFL & Castanea sativa & April 2021 \\
\hline $\begin{array}{c}\text { Roqes Blanques. } \\
\text { Park slope } \\
\text { stabilization }\end{array}$ & E. KRAINER & SLOPE & $\mathrm{NO}$ & HDFL & Castanea sativa & June 2017 \\
\hline $\begin{array}{c}\text { Garrotxa Natural } \\
\text { Parc slope } \\
\text { stabilization }\end{array}$ & E.SIMPLE & SLOPE & $\mathrm{NO}$ & HDFL & Castanea sativa & December 2020 \\
\hline $\begin{array}{c}\text { Garrotxa Natural } \\
\text { Parc slope } \\
\text { stabilization }\end{array}$ & E.SIMPLE & SLOPE & $\mathrm{NO}$ & HDFL & Castanea sativa & December 2020 \\
\hline $\begin{array}{l}\text { Roses Beach slope } \\
\text { stabilization }\end{array}$ & E. KRAINER & SEA & $\begin{array}{c}\text { tubular flexible } \\
\text { gabion }\end{array}$ & HDFL & Castanea sativa & $\begin{array}{c}\text { February/March } \\
2018\end{array}$ \\
\hline $\begin{array}{l}\text { Valldoreig Castle } \\
\text { slope stabilization }\end{array}$ & E.SIMPLE & SLOPE & NO & HDFL & Castanea sativa & December 2019 \\
\hline $\begin{array}{l}\text { Montmeló eschool } \\
\text { slope estabilization }\end{array}$ & E.SIMPLE & SLOPE & $\mathrm{NO}$ & HDFL & Castanea sativa & January 2019 \\
\hline $\begin{array}{l}\text { Serralada Marina } \\
\text { Natural Parc.Tiana. } \\
\text { Slope stabilization }\end{array}$ & E.SIMPLE & SLOPE & $\mathrm{NO}$ & HDFL & Castanea sativa & March 2019 \\
\hline $\begin{array}{c}\text { Barcelona Stream } \\
\text { Argentinina.Urban } \\
\text { area. }\end{array}$ & E.SIMPLE & SLOPE & $\mathrm{NO}$ & $\begin{array}{c}\text { tubular flexible } \\
\text { gabion }\end{array}$ & Castanea sativa & December 2019 \\
\hline $\begin{array}{l}\text { Begur Stream } \\
\text { Saltseseugues }\end{array}$ & E.SIMPLE & FLUVIAL & $\begin{array}{c}\text { tubular flexible } \\
\text { gabion }\end{array}$ & HDFL & $\begin{array}{c}\text { Pinus halepensis } \\
\mathcal{E} \text { Castanea } \\
\text { sativa }\end{array}$ & December 2020 \\
\hline
\end{tabular}


Table 3. Cont.

\begin{tabular}{|c|c|c|c|c|c|c|}
\hline Works & Type & Location & Foundation & Main Structure & Wood Spices & $\begin{array}{c}\text { Date of } \\
\text { Construction }\end{array}$ \\
\hline $\begin{array}{c}\text { Montornès del } \\
\text { Vallès. River Tenes }\end{array}$ & E. KRAINER & FLUVIAL & HDFL & HDFL & Castanea sativa & May 2020 \\
\hline $\begin{array}{l}\text { Castellar del Vallès } \\
\text { River Ripoll, } \\
\text { foodpath slope } \\
\text { stabilization }\end{array}$ & E.SIMPLE & SLOPE & $\mathrm{NO}$ & fascine & Castanea sativa & March 2020 \\
\hline $\begin{array}{l}\text { Sant Pere de Ribes } \\
\text { Millora del primer } \\
\text { tram del camí de } \\
\text { Puigmoltó }\end{array}$ & E.SIMPLE & SLOPE & NO & HDFL & Castanea sativa & February 2020 \\
\hline $\begin{array}{c}\text { Sant Antoni de } \\
\text { Vilamajor. Stream } \\
\text { Vilamajor }\end{array}$ & E. KRAINER & FLUVIAL & $\begin{array}{c}\text { tubular flexible } \\
\text { gabion }\end{array}$ & $\begin{array}{c}\text { tubular flexible } \\
\text { gabion }\end{array}$ & Castanea sativa & May 2021 \\
\hline $\begin{array}{c}\text { Cardedeu. River } \\
\text { Vallforners }\end{array}$ & E. KRAINER & FLUVIAL & $\begin{array}{c}\text { tubular flexible } \\
\text { gabion }\end{array}$ & HDFL & Castanea sativa & May 2015 \\
\hline $\begin{array}{c}\text { Tarroja de Segarra. } \\
\text { River Sió }\end{array}$ & E. KRAINER & FLUVIAL & fascine & fascine & Castanea sativa & March 2015 \\
\hline Sant Hilari Sacalm & E. KRAINER & FLUVIAL & fascine & fascine & $\begin{array}{c}\text { Pinus sylvestris } \\
\text { E Castanea } \\
\text { sativa }\end{array}$ & September 2008 \\
\hline $\begin{array}{c}\text { Barcelona. Park } \\
\text { Guell }\end{array}$ & E. SIMPLE & SLOPE & $\mathrm{NO}$ & fascine & Castanea sativa & April-July 2018 \\
\hline
\end{tabular}

\section{Results}

(A) Improvement of HDCL resistance for hydro-meteorological hazards.

All of the jobs visited show a good quality: the HDCL vegetated had vegetation in all lengths, the roll maintains the volume, so there were no holes due to fibers being dragged away. The biggest storm event detected was in Sant Quirze, where $4.18 \mathrm{~m} / \mathrm{s}$ velocity and $195.96 \mathrm{~N} / \mathrm{m}^{2}$ shear stress was achieved successfully, although, during the flooding, gabions in the same area of $900 \mathrm{~kg} / \mathrm{m}$ were moved by water (Table 4). The resistance of fiber rolls in the studied works depends more on the quality of the implantation than natural impacts. Although during the control time, there were no situations with tangential stress levels in any performance, and a limit situation was not observed. The fibers did not move due to the force of the water in any case, and the structure was maintained.

(B) Effects of HDCL on the growth and survival of plants.

Each species has shown different behaviors in the aerial growth variables concerning the treatments (Table 5). Lavandula angustifolia shows significant differences in diameter (Figure 4$)\left(\mathrm{F}_{(2,102)}=4.09, p<0.05\right)$ and close to significance in height (Figure 5) $\left(\mathrm{F}_{(2,102)}=2.97, p<0.1\right)$ between treatments. The posthoc test indicates significant differences $(p<0.05)$ between the treatment of two lines and the treatment of one line with the control. Despite differences in growth of more than $5 \mathrm{~cm}$ in Viburnum tinus with a positive trend in all treatments, the ANOVA model results in close to significance $\left(\mathrm{F}_{(2,133)}=2.95\right.$, $p<0.1)$ in diameter. In contrast, growth in height has an overall negative trend for treatments, with significant global differences $\left(\mathrm{F}_{(2,133)}=3.06, p<0.05\right)$ since the treatment of a single row obtained the worst diameter, although it is not significant in posthoc contrast $(p<0.1)$. Regarding the species Pistacia lentiscus, the two dependent variables of aerial growth showed differences between treatments; $\left(\mathrm{F}_{(2,137)}=4.52, p<0.05\right)$ for the diameter and $\left(\mathrm{F}_{(2,137)}=7.12, p<0.05\right)$ for the height (more than $\left.8 \mathrm{~cm}\right)$. In the Tukey test, the two variables show the effect that two HDCL lines have on aerial growth in both diameters 
$(p<0.05)$ and height $(p<0.05)$ concerning control. There are also differences in height between two lines and one $(p<0.05)$ with more than $6 \mathrm{~cm}$ difference.

Table 4. Hydraulic characteristics of the hydro-meteorological hazards that have affected the executed works.

\begin{tabular}{|c|c|c|c|c|c|}
\hline Place & HDCL Status & Date & $\begin{array}{c}\text { Peak Flow } \\
\left(\mathrm{m}^{3} / \mathrm{s}\right)\end{array}$ & $\begin{array}{l}\text { Velocity } \\
(\mathrm{m} / \mathrm{s})\end{array}$ & $\begin{array}{c}\text { Shear Stress } \\
\left(\mathrm{N} / \mathrm{m}^{2}\right)\end{array}$ \\
\hline \multirow{3}{*}{$\begin{array}{l}\text { Fluvià River, } \\
\text { Pont de les } \\
\text { mores (Olot) }\end{array}$} & \multirow{3}{*}{$\begin{array}{c}\text { Vegetated and } \\
\text { maintained } \\
\text { volume }\end{array}$} & $28 / 12 / 2008$ & 30.2 & 3.74 & \multirow{3}{*}{20.28} \\
\hline & & $14 / 04 / 2007$ & 13.27 & 1.61 & \\
\hline & & $01 / 02 / 2009$ & 11.39 & 1.38 & \\
\hline \multirow{3}{*}{$\begin{array}{l}\text { Anoia River, } \\
\text { Sant Esteve de } \\
\text { Ses Rovires }\end{array}$} & \multirow{3}{*}{$\begin{array}{l}\text { Vegetated and } \\
\text { maintained } \\
\text { volume }\end{array}$} & $10 / 10 / 2010$ & 13.72 & 2.88 & \multirow{3}{*}{9.54} \\
\hline & & $10 / 06 / 2010$ & 2.84 & 0.59 & \\
\hline & & $16 / 03 / 2011$ & 1.80 & 0.38 & \\
\hline \multirow{3}{*}{$\begin{array}{l}\text { Riu Mogent, } \\
\text { Llinars del } \\
\text { Vallès }\end{array}$} & \multirow{3}{*}{$\begin{array}{c}\text { Vegetated and } \\
\text { maintained } \\
\text { volume }\end{array}$} & $15 / 03 / 2011$ & 63.684 & 2.69 & \multirow{3}{*}{79.08} \\
\hline & & $13 / 09 / 2006$ & 15.61 & 0.65 & \\
\hline & & $27 / 02 / 2003$ & 11.83 & 0.50 & \\
\hline \multirow{3}{*}{$\begin{array}{l}\text { Fluvià River, } \\
\text { Besalú }\end{array}$} & \multirow{3}{*}{$\begin{array}{c}\text { Vegetated and } \\
\text { maintained } \\
\text { volume }\end{array}$} & $28 / 12 / 2008$ & 30.72 & 1.29 & \multirow{3}{*}{30.43} \\
\hline & & $14 / 04 / 2007$ & 13.27 & 0.55 & \\
\hline & & $01 / 02 / 2009$ & 11.39 & 0.48 & \\
\hline \multirow{3}{*}{$\begin{array}{l}\text { Congost River, } \\
\text { Granollers }\end{array}$} & \multirow{3}{*}{$\begin{array}{l}\text { Vegetated and } \\
\text { maintained } \\
\text { volume }\end{array}$} & $15 / 03 / 2011$ & 57.38 & 1.93 & \multirow{3}{*}{45.08} \\
\hline & & $02 / 11 / 2008$ & 9.62 & 0.62 & \\
\hline & & $13 / 02 / 2011$ & 5.93 & 0.19 & \\
\hline \multirow{3}{*}{$\begin{array}{c}\text { Besós River, } \\
\text { Montcada i } \\
\text { Reixac }\end{array}$} & \multirow{3}{*}{$\begin{array}{l}\text { Vegetated and } \\
\text { maintained } \\
\text { volume }\end{array}$} & $27 / 02 / 2003$ & 86.5 & 1.35 & \multirow{3}{*}{26.47} \\
\hline & & $13 / 09 / 2006$ & 82.53 & 1.29 & \\
\hline & & $04 / 12 / 2003$ & 54.98 & 0.86 & \\
\hline $\begin{array}{c}\text { Torrent de } \\
\text { Vallcorba, Sant } \\
\text { Quirze del } \\
\text { Vallès }\end{array}$ & $\begin{array}{l}\text { Vegetated and } \\
\text { maintained } \\
\text { volume }\end{array}$ & $17 / 09 / 2010$ & 42.43 & 4.18 & 195.96 \\
\hline
\end{tabular}

Table 5. Measurement results of structure of helophytic roots growing in HDFL fibers in three different environments. (Mean and Standard Error).

\begin{tabular}{cccc}
\hline & Wild Environment & $\begin{array}{c}\text { Controlled } \\
\text { Environment }\end{array}$ & $\begin{array}{c}\text { Vegetated } \\
\text { Coconut }\end{array}$ \\
\hline Stem diameter $(\mathrm{mm})$ & $8.9 \pm 1.4$ & $0.5 \pm 0.0$ & $0.5 \pm 0.1$ \\
\hline Aerial height $(\mathrm{cm})$ & $100.7 \pm 9.8$ & $39.5 \pm 1.2$ & $58.0 \pm 2.0$ \\
\hline Aerial width $(\mathrm{cm})$ & $71.4 \pm 19.7$ & $26.1 \pm 1.3$ & $37.7 \pm 2.5$ \\
\hline Root system's depth $(\mathrm{cm})$ & $41.2 \pm 2.72$ & $34.3 \pm 1.1$ & $49.3 \pm 2.4$ \\
\hline Root system's width $(\mathrm{cm})$ & $29.3 \pm 2.46$ & $15.7 \pm 0.8$ & $19.6 \pm 1.4$ \\
\hline Root system's volume $(\mathrm{mL})$ & $1260.5 \pm 376.7$ & $115.2 \pm 7.2$ & $216.9 \pm 15.6$ \\
\hline
\end{tabular}




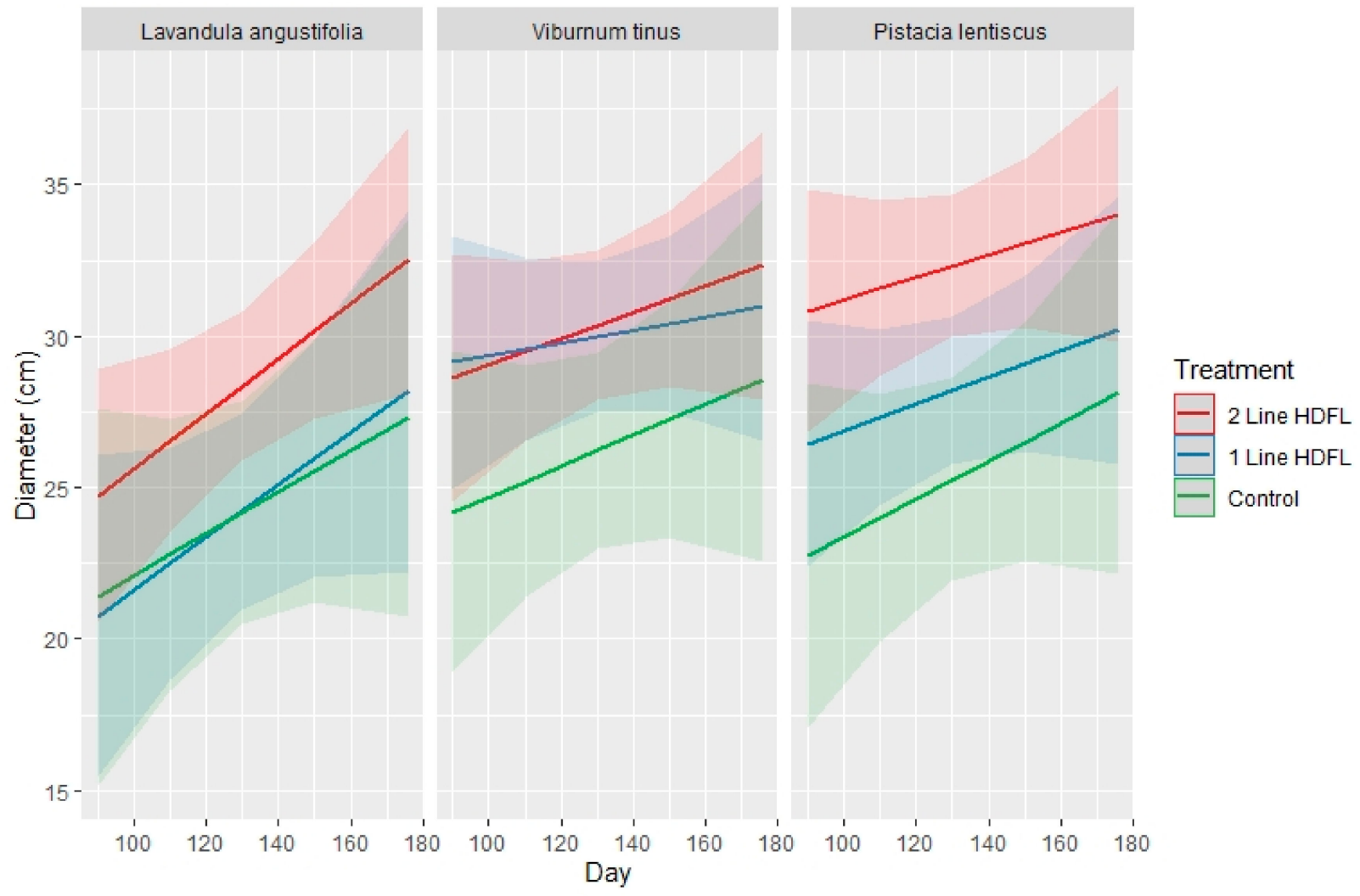

Figure 4. Plant diameter growth and HDCL influence. Subject Results. Effects of HDCL on the growth and survival of plants.

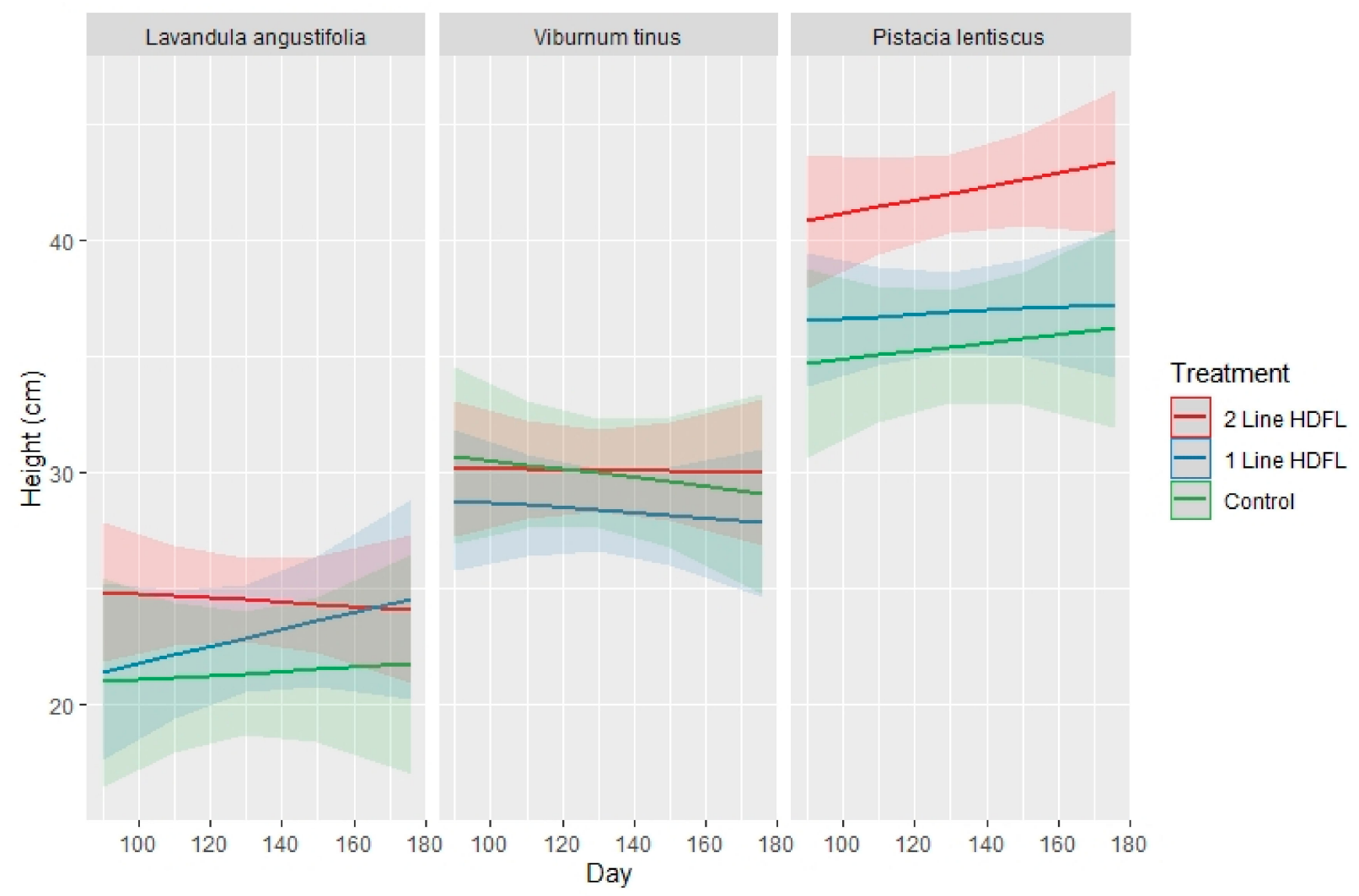

Figure 5. Plant height growth and HDCL influence. Subject Results. Effects of HDCL on the growth and survival of plants. 
In terms of mortality analysis, $60 \%$ of all species' analysis is concentrated in the control, $32 \%$ in a fiber roll one line and the remaining $8 \%$ with two lines. However, Fisher's test shows only a trend in significance $(p=0.08)$, so it cannot be completely ruled out that fiber rolls do not have an effect on plant survival.

(C) Colonization of HDCL by the roots.

The results of the ANOVAs show that, for the four species analyzed, only the relative stability index (S) is significant only for the species Iris pseudacorus $\left(\mathrm{F}_{(2,36)}=4.04, p<0.05\right)$ and Carex vulpine $\left(\mathrm{F}_{(2,36)}=26.06, p<0.05\right)$ (Table 6$)$. The post hoc analysis shows that these differences are attributed to the species Iris pseudacorus between controlled environment and plants that grow in a wild environment $(p<0.05)$. For Carex vulpina species, these differences also occur between the wild environment and vegetated fiber $(p<0.05)$.

Table 6. ANOVA and $t$-test results for each of the indexes. Subject Results. Colonization of HDCL by the roots.

\begin{tabular}{|c|c|c|c|c|}
\hline & $\begin{array}{c}\text { S: Relative } \\
\text { Stability Index }\end{array}$ & $\begin{array}{c}\text { s: Relative } \\
\text { Solidity Index }\end{array}$ & $\begin{array}{c}\text { R: Root System } \\
\text { Stability }\end{array}$ & $\begin{array}{l}\text { P: Global } \\
\text { Stability }\end{array}$ \\
\hline \multicolumn{5}{|c|}{ Juncus inflexus } \\
\hline $\mathrm{F}$ & 2.208 & 1.378 & 0.799 & 1.09 \\
\hline P effect & 0.125 & 0.265 & 0.458 & 0.347 \\
\hline \multicolumn{5}{|c|}{ Iris pseudacorus } \\
\hline $\mathrm{F}$ & 4.4 & 1.39 & 2.4 & 1.4 \\
\hline P effect & $<0.05$ & 0.26 & 0.10 & 0.25 \\
\hline \multicolumn{5}{|c|}{ Carex vulpina } \\
\hline $\mathrm{F}$ & 26.06 & 0.93 & 2.74 & 0.38 \\
\hline$P$ effect & $<0.05$ & 0.4 & $<0.1$ & 0.68 \\
\hline \multicolumn{5}{|c|}{ Scirpus Holoschoenus } \\
\hline $\mathrm{t}$ & 2.76 & 0.21 & 0.89 & -0.12 \\
\hline P effect & $<0.05$ & 0.83 & 0.38 & 0.91 \\
\hline \multicolumn{5}{|c|}{ Phragmites australis } \\
\hline $\mathrm{F}$ & 0.34 & 0.8 & 0.932 & 0.616 \\
\hline$P$ effect & 0.55 & 0.37 & 0.34 & 0.43 \\
\hline \multicolumn{5}{|c|}{ Carex pendula } \\
\hline $\mathrm{t}$ & 3.4 & 1.85 & 2.91 & 2.64 \\
\hline$P$ effect & $<0.05$ & 0.14 & $<0.05$ & $<0.05$ \\
\hline
\end{tabular}

For the species Scirpus holoschoenus and Carex pendula, the analysis of the $t$-test shows as significant, and therefore, it can be stated that the stability index is different for the nursery group concerning the group of the wild environment. Carex pendula also show significant differences in R (root system stability) and P (global stability).

(D) The success of crib wall soil bioengineering jobs with different characteristics and scenarios with the use of HDCL.

We analyzed the status of 23 works, and all were stabilized (Table 7). Naturalized is defined as when a crib wall looks vegetated; just a detailed observation shows the original structure. Commonly all the crib walls works became naturalized in five years. Nevertheless, in the CB fascine, works sometimes take longer. We only found holes in the $\mathrm{CB}$ fascine systems. We never observed any substantial damage. 
Table 7. Works with the crib wall characteristics and the results of the visits.

\begin{tabular}{|c|c|c|c|c|c|c|}
\hline Works & Type & & $\begin{array}{l}\text { Soil Stability } \\
\text { System }\end{array}$ & $\begin{array}{c}\text { Year of } \\
\text { Execution }\end{array}$ & Observation & Antiquity \\
\hline 1 & $\begin{array}{l}\text { Sant Cugat Stream } \\
\text { Can Cabassa }\end{array}$ & $\begin{array}{l}\text { E. KRAINER } \\
\text { /E.SIMPLE }\end{array}$ & HDFL & 2016 & naturalized & 5 \\
\hline 2 & $\begin{array}{l}\text { Palausolità i } \\
\text { Plegamans Riera } \\
\text { Sentmenat }\end{array}$ & E. KRAINER & fascine & 2011 & naturalized & 10 \\
\hline 3 & $\begin{array}{l}\text { Cànoves Riera de } \\
\text { Cànoves }\end{array}$ & E. KRAINER & fascine & 2016 & $\begin{array}{l}\text { stabilized but week in } \\
\text { naturalization due Robinia } \\
\text { pseudoacacia colonization } \\
\text { due proximity urban robinia } \\
\text { plantation }\end{array}$ & 5 \\
\hline 4 & $\begin{array}{l}\text { Santa Eulalia de } \\
\text { Ronçana.River } \\
\text { Tenes }\end{array}$ & E. KRAINER & HDFL & 2011 & naturalized & 10 \\
\hline 5 & $\begin{array}{l}\text { Santa Eulalia de } \\
\text { Ronçana.River } \\
\text { Tenes }\end{array}$ & E. KRAINER & $\begin{array}{l}\text { tubular flexible } \\
\text { gabion }\end{array}$ & 2016 & $\begin{array}{l}\text { stabilized, very succes in } \\
\text { flood resistence, but less } \\
\text { succes for plants }\end{array}$ & 5 \\
\hline 6 & $\begin{array}{l}\text { Sentmenat } \\
\text { Foodpath slope } \\
\text { stabilization }\end{array}$ & E. KRAINER & fascine & 2010 & $\begin{array}{l}\text { stabilized and close to } \\
\text { naturalization }\end{array}$ & 6 \\
\hline 7 & $\begin{array}{l}\text { La Garriga. River } \\
\text { Congost }\end{array}$ & E. KRAINER & fascine & 2011 & $\begin{array}{l}\text { naturalized but with risc } \\
\text { during the process (finally } \\
\text { success) due that fascine } \\
\text { diameters variation wholets } \\
\text { water enter in the Krainer } \\
\text { and take out soil. }\end{array}$ & 10 \\
\hline 8 & $\begin{array}{l}\text { Vacarisses-Urban } \\
\text { slope stabilization }\end{array}$ & E. KRAINER & HDFL & 2021 & Just finished & \\
\hline 9 & $\begin{array}{l}\text { Roqes Blanques. } \\
\text { Park slope } \\
\text { stabilization }\end{array}$ & E. KRAINER & HDFL & 2017 & $\begin{array}{l}\text { stabilized and close to } \\
\text { naturalization, good } \\
\text { management of stormwater. } \\
\text { Maintenance }\end{array}$ & 4 \\
\hline 10 & $\begin{array}{l}\text { Garrotxa Natural } \\
\text { Parc slope } \\
\text { stabilization }\end{array}$ & E.SIMPLE & HDFL & 2020 & $\begin{array}{l}\text { Recently finished, but good } \\
\text { progress }\end{array}$ & \\
\hline 11 & $\begin{array}{l}\text { Roses Beach slope } \\
\text { stabilization }\end{array}$ & E. KRAINER & HDFL & 2018 & $\begin{array}{l}\text { Stabilized and close to } \\
\text { naturalization, good } \\
\text { intrusion salinity protection } \\
\text { thangs fibers }\end{array}$ & 3 \\
\hline 12 & $\begin{array}{l}\text { Montmeló eschool } \\
\text { slope estabilization }\end{array}$ & E.SIMPLE & HDFL & 2019 & $\begin{array}{l}\text { stabilized, garden aspect, } \\
\text { good management of } \\
\text { stormwater. }\end{array}$ & 2 \\
\hline 13 & $\begin{array}{l}\text { Serralada Marina } \\
\text { Natural Parc.Tiana. } \\
\text { Slope stabilization }\end{array}$ & E.SIMPLE & HDFL & 2019 & $\begin{array}{l}\text { Stabilized but poorly } \\
\text { vegetated, the progress is } \\
\text { good but is a very dry area }\end{array}$ & 2 \\
\hline 14 & $\begin{array}{l}\text { Barcelona Stream } \\
\text { Argentinina.Urban } \\
\text { area. }\end{array}$ & E.SIMPLE & $\begin{array}{l}\text { tubular flexible } \\
\text { gabion }\end{array}$ & 2020 & $\begin{array}{l}\text { Recently finished, } \mathrm{d}, \text { in } \\
\text { correct progress }\end{array}$ & \\
\hline
\end{tabular}


Table 7. Cont.

\begin{tabular}{|c|c|c|c|c|c|c|}
\hline Works & Type & & $\begin{array}{l}\text { Soil Stability } \\
\text { System }\end{array}$ & $\begin{array}{c}\text { Year of } \\
\text { Execution }\end{array}$ & Observation & Antiquity \\
\hline 15 & $\begin{array}{l}\text { Begur Stream } \\
\text { Saltseseugues }\end{array}$ & E.SIMPLE & HDFL & 2020 & $\begin{array}{l}\text { Recently finished, but good } \\
\text { progress }\end{array}$ & \\
\hline 16 & $\begin{array}{l}\text { Montornès del } \\
\text { Vallès. River Tenes }\end{array}$ & E. KRAINER & HDFL & 2021 & $\begin{array}{l}\text { Recently finished, in correct } \\
\text { progress }\end{array}$ & \\
\hline 17 & $\begin{array}{l}\text { Castellar del Vallès } \\
\text { River Ripoll, } \\
\text { foodpath slope } \\
\text { stabilization }\end{array}$ & E.SIMPLE & fascine & 2021 & $\begin{array}{l}\text { Recently finished, in correct } \\
\text { progress }\end{array}$ & \\
\hline 18 & $\begin{array}{l}\text { Sant Pere de Ribes } \\
\text { Millora del primer } \\
\text { tram del camí de } \\
\text { Puigmoltó }\end{array}$ & E.SIMPLE & HDFL & 2020 & $\begin{array}{l}\text { Recently finished, in correct } \\
\text { progress }\end{array}$ & \\
\hline 19 & $\begin{array}{c}\text { Sant Antoni de } \\
\text { Vilamajor. Stream } \\
\text { Vilamajor }\end{array}$ & E. KRAINER & $\begin{array}{l}\text { tubular flexible } \\
\text { gabion }\end{array}$ & 2021 & Just finished & \\
\hline 20 & $\begin{array}{l}\text { Cardedeu. River } \\
\text { Vallforners }\end{array}$ & E. KRAINER & HDFL & 2015 & naturalized & 6 \\
\hline 21 & $\begin{array}{c}\text { Tarroja de Segarra. } \\
\text { River Sió }\end{array}$ & E. KRAINER & fascine & 2015 & naturalized & 6 \\
\hline 22 & Sant Hilari Sacalm & E. KRAINER & fascine & 2008 & naturalized & 13 \\
\hline 23 & $\begin{array}{l}\text { Barcelona. Park } \\
\text { Guell }\end{array}$ & E. SIMPLE & fascine & 2018 & $\begin{array}{l}\text { naturalized. Fast due } \\
\text { mantenance }\end{array}$ & 3 \\
\hline
\end{tabular}

\section{Discussion}

The crib wall soil and water bioengineering techniques are an excellent way to stabilize river slopes and landslide stabilization in the Mediterranean area. We observed that when using HDCL, this technic takes five years to become naturalized (fully vegetated), and longer if we use fascines.

The results of the work performed show that HDCL helps the plants to grow due to the capacity of water held. This capacity is not affected due to arid conditions. The plants observed growing show positive effects of the presence of coconut fiber rolls in all the controlled variables. The fact that the planting line with coconut fiber rolls on both banks was where fewer plants died, where more developed and where more flowers produced lavender could mean that the presence of coconut fiber rolls HDCL has a positive effect on vegetation. An interesting fact to finish the observations of this experiment would be the determination of the biomass of the plants, both of the aerial part and of the root system and, additionally, a qualitative study of the morphology of the roots by checking if there are differences in adaptation to water stress between the plants of the different planting lines (Control, F1, F2). On the one hand, it was observed that the species that best responded to the presence of coconut fiber was the mastic (Pistacia lentiscus), and the species that was less affected by the presence/absence of fiber rolls of coconut was the ivory (Viburnum tinus).

The data of root growth show that there is no difference in the root development between wild, cultivated or HDCL. Therefore, the log can become a suitable substrate for plants at a time that has mechanical properties. It would be exciting to know if this material can increase biodiversity in future research. It is also essential to highlight that the root system's structure index for helophytes is between good and very good, which confirms these species have a good root system development. In this respect, it can be emphasized that, on the contrary, for containers or pots, vegetated fiber rolls allow implementing well-developed plants in natural areas. The indexes of relative stability are approximately 
1 , which are not very high, but considering that the aerial part is flexible and does not offer the same resistance, we may consider it a good result. The same conclusions apply to the potential stability index. On the other hand, vegetated fiber rolls are closer to an ideal environment than a wild environment, achieving a good root system development of the plants, confirming it is a good system for introducing helophytes in natural areas.

Good resistance of vegetated fiber rolls was observed in restored areas, where $4.18 \mathrm{~m} / \mathrm{s}$ velocity was achieved successfully, although they were not installed in dynamical areas. The resistance of fiber rolls in the studied works depends more on the implantation quality than natural impacts, basically in the way to fix the rolls in the grown while the roots cannot be active in anchoring, such as in Anoia River.

The results show that the use of high-density coir logs (HDCL) has some advantages: stability against environmental changes, stability against flooding, plant grow and substrate capacity. All the visited crib walls were stable and successfully vegetated, but it is a fact that the ones with fascines have holes that can put the system at risk. The stability against environmental changes is due to the natural capacity of the fiber and the manufacturing of coir logs in the appropriate way (density). We cannot see any damage in the product on practical works installation of vegetated HDCL; no uptake of fiber was observed.

Although we have not conducted specific research on water retention by fascine, in this case, we detected two variables that make this technique less stable: fascine is made of material from the area, so they never have the same density. The density is not homogeneous. They are usually made from live branches, and we immediately notice a $20 \%$ reduction in diameter. Finally, the level of degradation of bundles in the Mediterranean area is very high. The level of coir fiber degradation is much lower than root growth. The density of the fiber roll makes that the colonization of the fiber structure by the plant is performed, in fact, by outstanding roots.

The force required to break a root increases linearly with increasing root diameter, but tensile strength is calculated per unit area. Therefore, smaller roots are stronger per unit area than large roots, decreasing root tensile strength with increasing root diameter [11]. Thus, fibers help to create a more resistant live structure. For the external stability analysis of such walls, the analysis can be performed as for other gravity retaining walls by assuming it is a monolithic construction, considering the composite body as a whole (Monolithic theory [12]) [1]. No articles discussing this study subject were found.

The success of naturalization of the crib wall after the visit of the different works performed are:

- The large density of plants; the crib wall is a hard box that is difficult to replant, so mortality of $20-40 \%$ is normal and does not affect the final success;

- It is essential to plant a significant diversity of species with the idea that each species have a particular adaptation capacity to the different conditions that the crib wall creates and increase success. Plant diversity is key to maintaining productive vegetation [13];

- Fascines in the Mediterranean cannot guarantee that water will not enter into the structure when daily variation in humidity and temperature;

- The introduction of rainwater in the system, but well-controlled, reduces the time of naturalization.

Author Contributions: Conceptualization, A.S.; methodology, A.S., E.P., B.M.-F., G.S.S., I.R., A.L.P. and C.U.; software, E.P.; validation, E.P.; formal analysis, A.S. and A.L.P.; investigation, A.S., E.P., B.M.-F., G.S.S., I.R. and A.L.P., resources, A.S., E.P., B.M.-F., G.S.S., I.R., A.L.P. and C.U.; data curation, A.S. and E.P.; writing-original draft preparation, A.S. and E.P.; writing-review and editing, A.S., E.P. and A.L.P. All authors have read and agreed to the published version of the manuscript.

Funding: This research was partially funded by OPEn-air laboRAtories for Nature baseD solutions to Manage environmental risks (OPERANDUM).

Institutional Review Board: Not applicable. 
Informed Consent Statement: Not applicable.

Acknowledgments: To our companions of Naturalea team: Salut Ribera, Xavi Sorolla, Mireia Gambús Teresa Navas and Eva Celda.

Conflicts of Interest: The authors declare no conflict of interest. The funders had no role in the design of the study; in the collection, analyses, or interpretation of data; in the writing of the manuscript, or in the decision to publish the results.

\section{References}

1. Acharya, M.S. Analytical Approach to Design Vegetative Crib Walls. Geotech. Geol. Eng. 2017, 36, 483-496. [CrossRef]

2. Bresci, E.; Preti, F. An Historical Survey on The Evolution of Some Forestwatershed Management Techniques (Part II: Stream Channel Works). J. Agric. Eng. 2010, 41, 13-22. [CrossRef]

3. Schiechtl, H. Bioengineering for Land Reclamation and Conservation; University of Alberta Press: Edmonton, AB, Canada, 1980.

4. Anselmo, V. L'Ingegneria naturalistica nella pratica professionale. In Le Sistemazioni Idraulico-Forestali con Tecniche di Ingegneria Naturalistica-Quaderni di Idronomia Montana; Editoriale Bios: Cosenza, Italy, 2008.

5. Correal, E.; Vilches, M. Guia de la Fusta de les Espècies Forestals de Catalunya, 2nd ed.; Institut Català de la Fusta, Goverment of Catalonia: Barcelona, Spain, 2012.

6. Malkapuram, R.; Kumar, V.; Negi, Y.S. Recent Development in Natural Fiber Reinforced Polypropylene Composites. J. Reinf. Plast. Compos. 2009, 28, 1169-1189. [CrossRef]

7. Mishra, L.; Basu, G. Coconut Fibre: Its structure, properties and applications. In Handbook of Natural Fibres Volume 1: Types, Properties and Factors Affecting Breeding and Cultivation Woodhead. Series in Textiles, 2nd ed.; Kozłowski, R.M., Mackiewicz-Talarczyk, M., Eds.; Elsevier: Amsterdam, The Netherlands, 2020; pp. 231-255.

8. Tomassini, L.; Foddai, S.; Ventrone, A.; Nicoletti, M. Iridoid glucosides from Viburnum tinus. Phytochemistry 1995, 3, $423-425$. [CrossRef]

9. Zrira, S.; Elamrani, A.; Benjilali, B. Chemical composition of the essential oil ofPistacia lentiscus L. from Morocco?a seasonal variation. Flavour Fragr. J. 2003, 18, 475-480. [CrossRef]

10. Prusinowska, R.; Śmigielski, K.B. Composition, biological properties and therapeutic effects of lavender (Lavandula angustifolia L.). A review. Herba Pol. 2014, 60, 56-66. [CrossRef]

11. Pollen, N.; Simon, A. Estimating the mechanical effects of riparian vegetation on stream bank stability using a fiber bundle model. Water Resour. Res. 2005, 41. [CrossRef]

12. Brandl, H. Konstruktive Hangsicherungen, Sonderdruck aus dem Grundbautaschenbuch. In Dritte Auflage, 3rd ed.; Wilhelm Ernst \& Sohn: Berlin, Germany, 1987; pp. 357-375.

13. Tilman, D.; Reich, P.B.; Knops, J.; Wedin, D.; Mielke, T.; Lehman, C. Diversity and Productivity in a Long-Term Grassland Experiment. Science 2001, 294, 843-845. [CrossRef] 